\title{
IMPLIKASI BERLAKUNYA PERATURAN PEMERINTAH NOMOR 46 TAHUN 2017 TENTANG INSTRUMEN EKONOMI LINGKUNGAN HIDUP TERHADAP KONSERVASI TANAH DAN AIR
}

(Implication of Goverment Regulation Number 46 of 2017 Concerning Environmental Economical Aspect Towards Water and Soil Conservation)

\author{
AL. Sentot Sudarwanto ${ }^{1}$ \\ ${ }^{1}$ Fakultas Hukum, dan Peer group PPLH LPPM Universitas Sebelas Maret \\ Jl. Ir. Sutami No.36 A, Pucangsawit, Kec. Jebres, Kota Surakarta, Jawa Tengah 57126, \\ Email: alsentotsudarwanto@yahoo.com
}

Diterima: 1 November 2019; Direvisi: 26 Maret 2020; Disetujui: 30 Maret 2020

\begin{abstract}
If the upstream community carries out the Soil and Water Conservation (SWC), whereas the downstream community participates in the benefits, therefore the upstream community needs to be rewarded with Payment Environmental Services (PES). This writing aims to analyze the logical consequences of the regulation of environmental economic instruments toward the SWC, especially related to environmental services. The research method is a normative juridical approach, using secondary data consisting of primary and secondary legal materials using qualitative analysis techniques. The results of the study show that the PES has been regulated in Government Regulation Number 46 of 2017 on Environmental Economic Instruments but there is no detailed regulation related to the calculation of SWC environmental services performed by downstream communities toward upstream communities. The Watershed Management Coordination Forum together with the government formed an Ad Hoc team whose task was to manage environmental service funds. Downstream communities pay for environmental services to the upstream communities as service providers through the environmental service management agencies. Therefore, the Ministry of Environment and Forestry of the Republic of Indonesia needs to immediately compile technical regulations on the mechanism and calculation of SWC from communities and governments in the downstream region to the government and communities in the upstream region.
\end{abstract}

\section{Keywords: Implication; instruments of living environmental economic; soil and water conservation}

\begin{abstract}
ABSTRAK
Apabila masyarakat wilayah hulu melakukan Konservasi Tanah dan Air (KTA), masyarakat bagian hilir ikut merasakan manfaatnya, oleh sebab itu masyarakat hulu perlu diberi Imbal Jasa Lingkungan (IJL). Penulisan ini bertujuan menganalisis konsekuensi logis pengaturan tentang instrumen ekonomi lingkungan hidup terhadap KTA khususnya terkait dengan jasa lingkungan. Metode penelitian dengan pendekatan yuridis normatif, menggunakan data sekunder yang terdiri dari bahan hukum primer dan bahan hukum sekunder dengan teknik analisis secara kualitatif. Hasil kajian menunjukkan IJL telah diatur dalam Peraturan
\end{abstract}


Pemerintah Nomor 46 Tahun 2017 Tentang Instrumen Ekonomi Lingkungan Hidup tetapi belum ada pengaturan secara rinci terkait penghitungan jasa lingkungan KTA yang dilakukan oleh masyarakat hilir kepada masyarakat hulu. Forum Koordinasi Pengelolaan DAS bersama pemerintah membentuk tim Ad Hoc yang memiliki tugas mengelola dana jasa lingkungan. Masyarakat hilir membayar jasa lingkungan kepada masyarakat hulu sebagai penyedia jasa melalui lembaga pengelola jasa lingkungan. Oleh karena itu, Kementerian Lingkungan Hidup dan Kehutanan RI perlu segera menyusun peraturan teknis tentang mekanisme dan penghitungan IJL KTA dari masyarakat dan pemerintah di wilayah hilir kepada pemerintah dan masyarakat di wilayah hulu.

\section{Kata kunci: Implikasi; Instrumen Ekonomi Lingkungan Hidup; KTA; DAS}

\section{PENDAHULUAN}

Sumber daya alam bisa diartikan sebagai segala sesuatu yang berada di lingkungan alam, dan manusia bisa memanfaatkannya untuk memenuhi kebutuhan hidupnya. Meningkatnya jumlah manusia berdampak pada semakin besarnya pemanfaatan sumber daya alam untuk pemenuhan kebutuhan hidupnya. Hal ini akan diikuti dengan munculnya berbagai permasalahan lingkungan yaitu menurunnya daerah resapan, penurunan kualitas lingkungan, dan berubahnya pola cuaca sehingga menyebabkan ketidakseimbangan antara pemanfaatan dan ketersediaan sumber daya dalam kuantitas dan kualitas yang memadahi. Hal ini merupakan ciri bahwa daya dukung Daerah Aliran Sungai (DAS) menurun, yang dapat mengakibatkan terganggunya perekonomian dan tata kehidupan masyarakat. Oleh karena itu, daya dukung DAS harus ditingkatkan dengan pengelolaan yang melibatkan masyarakat dan berbagai institusi yang punya tugas pokok fungsi terkait pengelolaan DAS. Pengelolaan DAS merupakan upaya manusia dalam mengatur hubungan timbal balik antara sumber daya alam dan manusia di dalam DAS serta segala aktivitasnya agar terwujud kelestarian dan keserasian ekosistem serta meningkatnya kemanfaatan sumber daya alam bagi manusia secara berkelanjutan.

Kebijakan dalam pengelolaan lingkungan hidup telah diatur, namun permasalahan lingkungan masih terus terjadi. Kebijakan yang mengatur tidak cukup untuk mengendalikan dan menyelesaikan permasalahan lingkungan, jika pelaksanaan dan pengawasannya cenderung normatif, sementara eksploitasi sumber daya terus dilakukan, maka terjadi degradasi lingkungan. Tanah dan air merupakan sumber daya vital sebagai penyangga kehidupan manusia dan makhluk hidup lainnya. Solusi permasalahan degradasi lingkungan khususnya tanah dan air adalah peraturan perundang-undangan terhadap perlindungan konservasi lingkungan, dan kebijakan publik lembaga pengelola KTA yang berkualitas, responsif dan aplikatif. (Samedi, 2015) menyebutkan faktor sosial dan ekonomi merupakan faktor dominan yang menjadi tantangan besar dalam upaya konservasi. Efektivitas pelaksanaan konservasi dapat dicapai dengan kelengkapan hukum yang memadai untuk 
membuat sumber daya alam bermanfaat secara berkelanjutan.

Menurut Undang-Undang Nomor 32 Tahun 2009 tentang Perlindungan dan Pengelolaan Lingkungan Hidup, pembayaran jasa lingkungan merupakan salah satu instrumen ekonomi sebagai bagian dari instrumen pengelolaan lingkungan hidup. Lingkungan beserta segenap komponen didalamnya memiliki peran dalam mendukung kehidupan, tetapi belum dipertimbangkan dalam sistem ekonomi. Hal ini menjadi dasar bagi konsep pembayaran jasa lingkungan. Perwujudan pembayaran jasa lingkungan berupa penghargaan atau reward yang diberikan oleh para pemanfaat air karena keberadaan air di dataran rendah dalam hal ini hilir sangat bergantung pada ketersediaan air yang ada di kawasan hulu (Sutopo, Sanim, Saukat, \& Mawardi, 2011). Selama ini masyarakat daerah hulu diminta untuk melakukan KTA, sedangkan masyarakat bagian hilir ikut merasakan manfaatnya. Masyarakat hilir sebagai penerima manfaat perlu membayar dana kompensasi sebagai imbal jasa kepada masyarakat hulu sebagai pengasil jasa lingkungan.

Pembayaran jasa lingkungan atau Payment for Environment Service (PES) merupakan pemberian penghargaan kepada pengelola atau penghasil jasa lingkungan dari suatu lahan atau ekosistem berupa pembayaran dana kompensasi/insentif atau dana konservasi untuk kepentingan pengelolaan. Salah satu program PES yang sudah dilaksanakan di Indonesia adalah Program Pengembangan Kebijakan dan
Percontohan PES atau IJL di DAS Krueng Montala, Jantho, Kabupaten Aceh Besar oleh Badan Perserikatan Bangsa-Bangsa (PBB) Komisi Ekonomi dan Sosial untuk Asia dan Pasifik (UN-ESCAP) bersama World Wide Fund for Nature (WWF) Indonesia Kantor Program Aceh dan Badan Pengelola Dampak Lingkungan Daerah (Bapedalda) Aceh sejak Desember 2011 (Wardah \& Farsia, 2013). Menurut Wardah dan Farsia (2013), pelaksanaan Program PES di Krueng Montala ini, terdapat beberapa hal yang perlu dievaluasi antara lain, pertama perangkat hukum di tingkat nasional dan lokal belum mendukung pelaksanaan program PES khususnya untuk jasa lingkungan air, karena belum adanya mekanisme standar yang disepakati untuk pelaksanaan PES. Kedua, mekanisme dan standar pembayaran PES di Krueng Montala masih pada tahap awal, sehingga masyarakat belum mendapatkan manfaat ekonomi secara langsung.

Program IJL saat ini telah diatur dalam Undang-Undang Nomor 37 Tahun 2014 Tentang Konservasi Tanah dan Air dan Peraturan Pemerintah Nomor 46 Tahun 2017 Tentang Instrumen Ekonomi Lingkungan Hidup. Dalam pengelolaan DAS selama ini masyarakat daerah hulu melakukan KTA dan masyarakat bagian hilir ikut merasakan manfaatnya. Masyarakat hilir sebagai penerima manfaat perlu membayar dana kompensasi sebagai imbal jasa kepada masyarakat hulu, maka perlu dipikirkan mekanisme pemberian kompensasinya. Sampai saat ini, pengaturan mengenai mekanisme pemberian dan penghitungan IJL KTA dari masyarakat dan pemerintah di 
wilayah hilir kepada pemerintah dan masyarakat di wilayah hulu belum ada. Berdasarkan masalah tersebut di atas, tujuan dari penelitian ini adalah menganalisis konsekuensi logis pengaturan tentang instrumen ekonomi lingkungan hidup terhadap KTA khususnya terkait dengan IJL.

\section{BAHAN DAN METODE}

Penelitian ini menggunakan pendekatan yuridis normatif yaitu dengan mencermati pijakan yuridis yang mengatur tentang topik persoalan penelitian.

Jenis data dalam penelitian ini adalah data sekunder yaitu data yang diperoleh dari kajian literatur, sedangkan sumber data terdiri dari bahan hukum primer dan bahan hukum sekunder. Bahan hukum primer terdiri dari Undang-Undang Republik Indonesia Nomor 32 Tahun 2009 tentang Perlindungan dan Pengelolaan Lingkungan Hidup, Undang-Undang Republik Indonesia Nomor 37 Tahun 2014 tentang Konservasi Tanah dan Air, serta Peraturan Pemerintah Nomor 46 Tahun 2017 Tentang Instrumen Ekonomi Lingkungan Hidup. Bahan hukum sekunder terdiri dari literatur dan jurnal nasional maupun internasional yang mengkaji tentang IJL.

Setelah data sekunder yang diperlukan di dalam penelitian ini terkumpul, maka selanjutnya dilakukan analisis data menggunakan analisis kualitatif.

\section{HASIL DAN PEMBAHASAN}

\section{A. Konservasi Tanah dan Air}

Tanah dan air merupakan sumberdaya alam utama sebagai penyokong kehidupan makhluk hidup di bumi. Kedua sumber daya tersebut mudah mengalami kerusakan dan terdegradasi terutama karena berbagai aktivitas pembangunan seperti kegiatan pertanian, industri, infrastuktur, serta perumahan. Degradasi lahan juga dapat disebabkan oleh pembukaan atau pemanfaatan hutan yang hanya berorientasi ekonomi tanpa memperhatikan kaidah lingkungan baik melalui kegiatan pengusahaan hutan, konversi kawasan hutan menjadi areal pertambangan, perkebunan, dan pemukiman yang kurang terencana dengan baik. Kerusakan tanah bisa terjadi karena hilangnya unsur hara, erosi tanah, serta pencemaran tanah. Adapun kerusakan air dapat berupa mengeringnya mata air atau berkurangnya debit air, penurunan kualitas air akibat sedimentasi, dan pencemaran air. Jika tanah dan air mengalami kerusakan maka fungsi utama tanah sebagai penopang kehidupan akan terganggu. Oleh karena itu, diperlukan upaya KTA untuk menjaga kualitasnya agar dapat dimanfaatkan secara berkelanjutan. Hal ini merupakan tanggung jawab dan kewajiban pemerintah bersama masyarakat. Konservasi sumber air penting untuk dilakukan salah satunya dengan cara vegetatif melalui penanaman lahan kritis 
di daerah tangkapan air. Salah satu contoh upaya konservasi air yang berpotensi untuk pengembangan IJL (payment for enviromental services) sekaligus upaya dalam menekan deforestasi adalah kegiatan pemanfaatan jasa lingkungan air di Kawasan Suaka Alam Marapi Provinsi Sumatera Barat (Riska, Bambang, \& Budiyono, 2013). Penerapan pembayaran jasa lingkungan untuk kegiatan rehabilitasi hutan dan lahan merupakan salah satu solusi untuk mengatasi kerusakan fungsi hidrologi Sub DAS Way Betung Kabupaten Pesawaran Provinsi Lampung dengan bentuk pembayaran berupa uang tunai, pembangunan pedesaan, bantuan bibit dan pupuk dan hewan ternak (Arafat, Wulandari, \& Qurniati, 2015).

Undang-Undang Nomor 37 Tahun 2014 Tentang Konservasi Tanah dan Air, menyebutkan bahwa KTA merupakan upaya pelindungan, pemulihan, peningkatan, dan pemeliharaan fungsi tanah pada lahan sesuai dengan kemampuan dan peruntukan lahan untuk mendukung pembangunan yang berkelanjutan dan kehidupan yang lestari. Berbagai tindakan konservasi tanah juga merupakan tindakan konservasi air dimana setiap perlakuan yang diberikan pada suatu wilayah DAS, akan mempengaruhi tata air pada wilayah tersebut dan tempat-tempat di hilirnya. Kegiatan KTA antara lain meliputi pengendalian erosi dan banjir, pengaturan pemanfaatan air, peningkatan daya guna lahan, peningkatan produksi dan pendapatan petani termasuk peningkatan peran serta masyarakat (Wahyudi, 2014).
Salah satu upaya untuk meningkatkan produksi pangan, meningkatkan produktivitas lahan secara berkelanjutan dan menjaga kelestarian lingkungan dapat dilakukan dengan pemanfaatan lahan kering berlereng dengan menerapkan teknologi KTA yang tepat (Heryani \& Sutrisno, 2013). Penelitian yang dilakukan Katharina (2007) pada usaha tani kentang menunjukkan bahwa usaha pertanian yang menerapkan teknik konservasi memperoleh pendapatan yang lebih rendah daripada yang tidak menerapkan teknik konservasi. Namun demikian analisis jangka panjang (20 tahun ke depan), usaha tani yang menerapkan teknik konservasi memberikan keuntungan yang lebih tinggi daripada tidak mengadopsi teknik konservasi. Hal ini menunjukkan bahwa konservasi yang dilakukan petani sekarang atau saat ini merupakan investasi jangka panjang dan berkelanjutan. Oleh karena itu, petani yang menerapkan teknik konservasi terhadap lahan usahataninya harus diberikan insentif dan kepada masyarakat yang melakukan kegiatan konservasi diberikan imbal jasa terhadap konservasi yang dilakukannya.

Koordinasi di antara para stakeholder, instansi terkait dan peningkatan peran serta masyarakat dalam penerapan KTA diperlukan untuk pengembangan teknologi KTA dalam sistem usaha tani yang berkelanjutan. Peran serta masyarakat di dalam KTA melalui berbagai upaya pemberdayaan yang diarahkan dan digerakkan oleh pemerintah melalui penyuluhan dan pelatihan. Untuk mengikutsertakan masyarakat dalam penyelenggaraan KTA maka dilaksanakan 
pendekatan pengelolaan DAS terpadu berbasis masyarakat.

Pengelolaaan DAS berbasis masyarakat dilaksanakan secara terencana dan terpadu bersifat parsitipatif dengan melibatkan peran serta berbagai unsur masyarakat bersama-sama pemerintah baik provinsi maupun kabupaten/kota serta unsur swasta yang berpengaruh terhadap keberhasilan pengelolaan DAS. Para pihak terkait pengelolaan DAS yaitu Pemerintah Pusat, Pemerintah Daerah Provinsi dan Pemerintah Kabupaten/Kota, LSM Pemerhati Lingkungan Hidup, sektor swasta/pelaku usaha, Kelompok tani dan masyarakat, akademisi, Lembaga Masyarakat Desa dan Hutan (LMDH) dan Forum Koordinasi pengelolaan DAS. Hal tersebut dimaksudkan agar semua institusi yang berkepentingan bersamasama dengan masyarakat untuk melakukan pengelolaan DAS secara terintegerasi. Oleh karena sistem pemerintahan di Indonesia berbasis administrasi maka perlu pijakan yuridis berupa Peraturan Daerah (Perda) tentang pengelolaan DAS, dimana salah satu klausul pasalnya menyebutkan kerjasama lintas daerah dalam pengelolaan DAS antar wilayah. Oleh karena itu, kegiatan KTA melalui pengelolaan DAS berbasis masyarakat yang dilaksanakan secara terencana dan terpadu perlu dilakukan dengan sistem partisipatif agar masyarakat sadar terhadap pentingnya lingkungan, terutama tanah dan air, sehingga masyarakat tergerak untuk melaksanakan konservasi di lingkungan sekitarnya melalui kerjasama antar pemilik kepentingan, yakni masyarakat, swasta dan pemerintah.
B. Imbal Jasa Lingkungan Sebagai Kewajiban Kompensasi Pemerima Kemanfaatan Hasil Konservasi Tanah Dan Air

1. Pijakan yuridis pengaturan imbal jasa lingkungan

a) Undang-undang Nomor 37 Tahun 2014 Tentang Konservasi Tanah dan Air

Penyelenggaraan KTA diatur dalam Undang-Undang Nomor 37 Tahun 2014 Tentang Konservasi Tanah dan Air (UUKTA). Konservasi tanah dan air dilaksanakan berdasarkan asas: partisipatif, keterpaduan, keseimbangan, keadilan, kemanfaatan, kearifan lokal,, dan kelestarian.

Pasal 3 UUKTA, disebutkan bahwa tujuan penyelenggaraan konservasi tanah dan air adalah melindungi permukaan tanah dari pukulan air hujan yang jatuh, meningkatkan kapasitas infiltrasi tanah, dan mencegah terjadinya konsentrasi aliran permukaan; menjamin dan mengoptimalkan fungsi tanah pada lahan agar mendukung kehidupan masyarakat untuk mewujudkan manfaat ekonomi, sosial, dan lingkungan hidup secara seimbang dan lestari; meningkatkan daya dukung DAS; meningkatkan kemampuan untuk mengembangkan kapasitas dan memberdayakan keikutsertaan masyarakat secara partisipatif; dan menjamin kemanfaatan KTA secara adil dan merata untuk kepentingan masyarakat.

Pasal 5 dan 6 UUKTA memberi kewenangan kepada Pemerintah untuk mengatur dan menyelenggarakan KTA atau dapat melimpahkan sebagian kewenangannya kepada perangkat 
Pemerintah atau wakil Pemerintah di daerah atau dapat menugaskannya kepada Pemerintah Daerah sesuai dengan ketentuan peraturan perundangundangan. Selanjutnya di dalam Pasal 7, disebutkan bahwa yang bertanggungjawab terhadap penyelenggaraan KTA adalah Pemerintah, Pemerintah Daerah, pemegang hak atas tanah, pemegang kuasa atas tanah, pemegang izin, dan/atau pengguna lahan yang wajib mengikuti prinsip konservasi dan menghormati hak yang dimiliki setiap orang. Pelaksanaan penyelenggaraan KTA dilaksanakan berdasarkan unit DAS, ekosistem, dan satuan lahan yang dilakukan dengan menggunakan pendekatan pengelolaan DAS secara terpadu dan berbasis masyarakat.

Dalam hal pendanaan sebagaimana diatur pada Pasal 31 UUKTA, Pendanaan penyelenggaraan KTA menjadi tanggung jawab Pemerintah dan/atau Pemerintah Daerah, pemegang hak atas tanah, pemegang kuasa atas tanah, pemegang izin, dan/atau pengguna lahan, baik sendiri-sendiri maupun bekerja sama. Sumber pendanaan dapat berasal dari Anggaran Pendapatan dan Belanja Negara (APBN), badan hukum, badan usaha, perseorangan, dan/atau sumber lain yang sah dan tidak mengikat berdasarkan peraturan perundang-undangan. Sumber lain yang sah dan tidak mengikat, termasuk yang berasal dari pembayaran IJL terhadap penyelenggaraan konservasi tanah dan Air. Pengelolaan sumber pendanaan, harus dilakukan secara transparan dan akuntabel.
Pembayaran IJL dalam penyelenggaraan KTA dikenakan kepada Pemerintah dan/atau Pemerintah Daerah dan penerima manfaat atas sumber daya Tanah dan Air sebagaimana diatur dalam Pasal 32 UUKTA. Selanjutnya dalam Pasal 33 UUKTA, kewajiban/tanggung jawab membayar pemanfaat jasa lingkungan yaitu Pemerintah dan/atau Pemerintah Daerah untuk penyelenggaraan KTA terkait kewajiban pelayanan publik yang menyangkut hajat hidup orang banyak dan penerima manfaat atas sumber daya tanah dan air bertanggung jawab membayar untuk kepentingan penyelenggaraan KTA.

Berdasarkan hal tersebut penyelenggaraan KTA dalam pengelolaan DAS menjadi tanggungjawab semua pihak yang berkepentingan dan yang mendapat manfaat dari kelestarian lingkungan DAS, maka pemerintah kabupaten/kota dan masyarakat yang mendapat manfaat atau memanfaatkan tanah dan air berkewajiban untuk turut serta dalam upaya KTA melalui pembayaran IJL kepada pemerintah atau masyarakat penghasil jasa lingkungan. Peran aktif masyarakat dalam pengelolaan DAS dapat berupa pengelolaan jasa lingkungan dan partisipasi aktif masyarakat dalam penyelenggaraan KTA.

b) Peraturan Pemerintah Nomor 46 Tahun 2017 Tentang Instrumen Ekonomi Lingkungan Hidup

Peraturan Pemerintah Nomor 46 Tahun 2017 Tentang Instrumen Ekonomi Lingkungan Hidup di dalam Pasal 4, menyebutkan bahwa IJL merupakan salah satu instrumen perencanaan 
pembangunan dan kegiatan ekonomi yang dilaksanakan oleh pemerintah pusat dan daerah. Perencanaan dan penyelenggaraan pembangunan dan kegiatan ekonomi antara lain pengelolaan Sumber Daya Alam (SDA), penataan ruang, konservasi SDA dan pelestarian fungsi lingkungan hidup.

Pasal 10, kompensasi/IJL antar daerah diberikan oleh Pemanfaat Jasa Lingkungan Hidup atas manfaat dan/atau akses terhadap Jasa Lingkungan Hidup yang dikelola dan/atau dipulihkan oleh Penyedia Jasa Lingkungan Hidup. Salah satu jasa lingkungan hidup yang diberikan imbal jasa adalah perlindungan tata air. Selanjutnya di Pasal 11, bentuk kompensasi/IJL antar daerah meliputi uang; atau sesuatu lainnya yang dapat dinilai dengan uang yang nilainya ditentukan dengan mempertimbangkan biaya ekonomi upaya pelestarian fungsi lingkungan hidup; biaya pemberdayaan masyarakat; dan biaya pelaksanaan kerjasama.

Pasal 14, kompensasi/IJL antar daerah antara Pemerintah Pusat dengan Pemerintah Daerah serta antar Pemerintah Daerah dilaksanakan melalui mekanisme: hibah daerah dari Pemerintah Pusat selaku Pemanfaat Jasa Lingkungan Hidup kepada Pemerintah Daerah selaku Penyedia Jasa Lingkungan Hidup atau sebaliknya; atau hibah daerah atau belanja bantuan keuangan urusan lingkungan hidup dari Pemerintah Daerah selaku Pemanfaat Jasa Lingkungan Hidup kepada Pemerintah Daerah selaku Penyedia Jasa Lingkungan Hidup dituangkan dalam perjanjian kerjasama.
Perjanjian kerjasama paling sedikit memuat: para pihak; tujuan; jumlah; sumber pendanaan; persyaratan; tata cara penyaluran; tata cara pelaporan dan pemantauan; dan hak dan kewajiban pemberi dan penerima sebagaimana diatur dalam Pasal 15. Selanjutnya pada Pasal 16, disebutkan bahwa dalam melaksanakan kerjasama kompensasi/ IJL antar daerah antara Penyedia Jasa Lingkungan Hidup dan Pemanfaat Jasa Lingkungan Hidup dapat membentuk wadah atau forum kerjasama Kompensasi/Imbal Jasa Lingkungan Hidup Antar Daerah; dan/atau meminta bantuan fasilitator. Sebagai fasilitator yaitu Pemerintah Pusat atau Pemerintah Daerah Provinsi sesuai kewenangannya; dan/atau fasilitator yang berasal dari orang perseorangan, organisasi lingkungan hidup, perguruan tinggi, atau organisasi lain yang disepakati.

Pasal 47, diatur mengenai pembayaran jasa lingkungan hidup yaitu berupa fasilitasi mekanisme pengalihan sejumlah uang dari Pemanfaat Jasa Lingkungan Hidup kepada Penyedia Jasa Lingkungan Hidup dalam perjanjian terikat berbasis kinerja guna mendorong masyarakat untuk melaksanakan upaya Konservasi Sumber Daya Alam dan Pelestarian Fungsi Lingkungan Hidup dan mendukung kinerja pelaksanaan Kompensasi/Imbal Jasa Lingkungan Hidup Antar Daerah.

\section{Pelaksanaan Imbal Jasa Lingkungan di beberapa daerah}

Pemanfaatan sumber daya alam yang melampaui batas akan mempengaruhi ketersediaan jasa lingkungan di masa yang akan datang. Pemanfaatan kawasan 
hutan, sumber daya air dan sumber daya alami lainnya memungkinkan adanya IJL untuk diterapkan sehingga berkelanjutan. IJL diartikan sebagai sistem pemberian imbalan kepada penghasil jasa lingkungan untuk meningkatkan kualitas dan kuantitas jasa lingkungan. Instrumen IJL sebagai instrumen pengelolaan lingkungan yang strategis dalam perlindungan sumberdaya alam dan lingkungan yang sekaligus akan memberdayakan dan memperbaiki kehidupan sosial ekonomi masyarakat sekitarnya (Sudarma, 2014). Dalam pelaksanaan sistem pembayaran jasa lingkungan perlu diidentifikasi agen ekonomi yang bertanggungjawab sebagai penyedia jasa dan agen lain sebagai penerima manfaat dengan membangun hubungan sebab-akibat yang diperlukan yaitu hubungan antara wilayah hulu (upstream) kepada keadaan sumberdaya air di wilayah hilir (down-stream) dalam DAS yang bersangkutan (Dasrizal, Ansofino, Juita, \& Jolianis, 2012).

Pada dasarnya tujuan dari IJL adalah untuk merestorasi dan melindungi ketersediaan barang dan jasa lingkungan yang berkelanjutan. Misalnya, pembayaran jasa lingkungan di Kecamatan Jailolo Kabupaten Halmahera Barat sebagai perlindungan ekosistem mangrove yang memberikan manfaat sebagai sumber air, tambak, wisata, maupun sebagai perlindungan daerah pesisir (Idrus, Ismail, \& Ekayani, 2016). Peraturan perundangan yang mengatur mengenai IJL sudah ada yaitu UndangUndang Nomor 37 Tahun 2014 tentang Konservasi Tanah dan Air dan Peraturan Pemerintah Nomor 47 Tahun 2017
Tentang Instrumen Ekonomi Ligkungan Hidup. Konsep IJL sudah dilakukan di beberapa wilayah di Indonesia. Namun, dalam pelaksanaan IJL, masing-masing daerah memiliki mekanismenya sendiri didasarkan pada kebutuhan serta kearifan lokalnya.

Di Kabupaten Lombok Barat sudah membentuk suatu wadah organisasi pengelolaan jasa lingkungan sumberdaya air untuk melestarikan kawasan konservasi melalui kesediaan untuk membiayai kegiatan konservasi dan perbaikan ekonomi bagi kelompok masyarakat miskin di daerah hulu melalui penarikan uang pembayaran jasa lingkungan sebesar antara Rp 500,- - Rp 5.000,- bagi pelanggan Perusahaan Daerah Air Minum (PDAM), dari dana yang terkumpul sebesar $75 \%$ akan digunakan untuk upaya konservasi dan pengentasan kemiskinan, dan 25\% akan disetorkan ke Kas Pemerintah Daerah (Sudiyono, 2012). Sebagai dasar hukumnya adalah Peraturan Daerah Nomor 4 Tahun 2007 tentang Pengelolaan Jasa Lingkungan, Peraturan Bupati Lombok Barat Nomer 7 Tahun 2009 tentang Susunan Organisasi, Tata Kerja, Tugas dan Wewenang Institusi Multi Pihak (IMP) sebagai petunjuk pelaksanaannya. Serta Keputusan Bupati Lombok Barat Nomer 1072/207/Dishut/2009 tentang Pembentukan Institusi Multi Pihak Pengelolaan Jasa Lingkungan Kabupaten Lombok Barat, serta Peraturan Bupati Lombok Barat Nomer 42 tahun 2008 Tentang Obyek, Tarif, Tata Cara Pembayaran dan Sanksi Administratif. Program IJL di Krueng Montala Aceh dalam pelaksanaannya terdapat beberapa 
hal yang perlu dievaluasi, pertama perangkat hukum di tingkat nasional dan lokal karena belum adanya mekanisme standar yang disepakati. Kedua, mekanisme dan standar pembayaran PES di Krueng Montala masih pada tahap awal, sehingga masyarakat belum mendapatkan manfaat ekonomi secara langsung (Wardah \& Farsia, 2013). Contoh lain adalah kesepakatan program IJL di Sub-DAS Cikapundung, Jawa Barat antara Kelompok Tani Giri Putri Desa Cikole dengan Pustanling, serta Kelompok Tani Syurga Air Desa Suntenjaya sebagai penyedia jasa dengan PT. Aetra Air Jakarta sebagai pemanfaat jasa dan Badan Pengelola Lingkungan Hidup Daerah (BPLHD) Kabupaten Bandung berperan sebagai mediator dalam kesepakatan ini. Pada pelaksanaannya, mekanisme IJL di Sub-DAS Cikapundung dikategorikan sebagai mekanisme IJL yang belum sepenuhnya mencerminkan mekanisme IJL yang berkelanjutan, karena masalah kelembagaan dalam pengelolaan dan monitoring perkembangannya di lapangan. Selain itu dana yang diberikan kepada kelompok tani juga masih tergolong belum mencukupi untuk aktivitas konservasi lahan (Napitupulu, Asdak, \& Budiono, 2013). Penerapan pembayaran jasa lingkungan juga dilakukan di Kecamatan Jailolo Kabupaten Halmahera Barat. Pembayaran jasa dilakukan terhadap dua jenis jasa yang menjadi potensi untuk diinisiasi pembayaran jasa lingkungan yaitu jasa pengatur dari intrusi air laut dan jasa budaya dari wisata mangrove. Penerapan pembayaran jasa sangat ditentukan dari bagaimana mengidentifikasi jasa potensial, yaitu dengan menentukan nilai ekonomi, pemanfaat, dan penyedia jasa lingkungan mangrove serta mekanisme pembayaran (Idrus et al., 2016).

Berdasarkan beberapa permasalahan yang terjadi dalam implementasi IJL, maka partisipasi berbagai pihak perlu dilakukan secara terpadu dan terintegerasi, diperlukan peningkatan kapasitas kelembagaan, dan yang paling penting adalah pemerintah harus memberikan payung hukum baik ditingkat nasional maupun daerah sebagai dasar pijakan bagi pelaksanaan IJL agar berkelanjutan.

\section{Norma Hukum/ Peraturan Pelaksanaan yang Diharapkan.}

Pasal 34 Undang-Undang Nomor 37 Tahun 2014 Tentang Konservasi Tanah dan Air mengamanatkan pengaturan lebih lanjut mengenai IJL dan pendanaan penyelenggaraan KTA dalam bentuk Peraturan Pemerintah dan perlu diatur lebih lanjut secara teknis dalam bentuk peraturan menteri. Sampai saat ini Peraturan Pemerintah yang dimaksud belum terwujud sebagaimana amanat UUKTA

Pengaturan mengenai imbal jasa lingkungan telah diatur dalam Peraturan Pemerintah Nomor 46 Tahun 2017 Tentang Instrumen Ekonomi Lingkungan Hidup sebagai pelaksanaan ketentuan Pasal 43 Ayat (4) dan Pasal 55 Ayat (4) Undang-Undang Nomor 32 Tahun 2009 Tentang Perlindungan dan Pengelolaan Lingkungan Hidup. Sebagaimana disebutkan pada Pasal 47, bahwa IJL hidup merupakan salah satu instrumen ekonomi lingkungan hidup sebagai insentif dengan pengembangan sistem pembayaran jasa 
lingkungan hidup. Selanjutnya pada Pasal 48 Peraturan Pemerintah Nomor 46 Tahun 2017 mengamanatkan pengaturan lebih lanjut mengenai pengembangan sistem Pembayaran Jasa Lingkungan Hidup dalam bentuk Peraturan Menteri dalam hal ini Kementerian Lingkungan Hidup dan Kehutanan.

Kementerian Lingkungan Hidup dan Kehutanan berkewajiban untuk menterjemahkan amanat Peraturan Pemerintah Nomor 46 Tahun 2017 tersebut untuk dibuat sebuah petunjuk pelaksanaan tentang pengaturan mekanisme atau penghitungan IJL yang sampai saat ini belum ada. Hal tersebut karena Kementerian Lingkungan Hidup sedang disibukkan dengan pembuatan berbagai peraturan teknis sebagai amanat dari peraturan pemerintah tentang Perizinan Berusaha Terintegerasi Secara Elektronik atau Online Single Submission (OSS). Akibatnya persoalan pemberian IJL ini belum bisa dilaksanakan dengan baik dan benar oleh masyarakat dan pemerintah wilayah hilir.

Peraturan Menteri lingkungan hidup dan kehutanan mengenai pengembangan sistem Pembayaran Jasa Lingkungan Hidup, sebagai pelaksanaan dari amanat yang ada pada Peraturan Pemerintah Nomor 46 Tahun 2017 Tentang Instrumen Ekonomi Lingkungan Hidup, belum ada. Apabila kepentingan daerah mendesak terkait dengan pembayaran IJL hidup, maka daerah bisa membuat peraturan daerah yang mengatur mengenai para pihak, tujuan, jumlah, sumber pendanaan, persyaratan, tata cara penyaluran, tata cara pelaporan dan pemantauan, serta hak dan kewajiban pemberi dan penerima IJL. Peraturan Daerah tersebut dibuat sesuai dengan kebutuhan pengaturan IJL yang spesifik untuk masing-masing daerah.

\section{Model Mekanisme Pembayaran Imbal Jasa Lingkungan Konservasi Tanah Dan} Air

Kerjasama antara hulu dan hilir juga menjadi salah satu indikator keterpaduan dalam pengorganisasian pengelolaan DAS. Selama ini kerjasama pembayaran jasa lingkungan belum dapat berjalan karena partisipasi para pihak masih rendah dan belum berjalan secara kontinyu dan terkoordinasi. Skema kerjasama melalui pembayaran jasa lingkungan adalah dengan membangun kerjasama para pihak yang mendapatkan manfaat yaitu masyarakat bagian tengah dan hilir berkontribusi dalam perbaikan kerusakan DAS bagian hulu sehingga ketersediaan air dapat terjaga (Fatahilah, 2013). Untuk menginisiasi dan menjembatani kerjasama antara pihak yang membutuhkan jasa lingkungan yang berada di hilir DAS dengan pengelola lingkungan yang berada di ekosistem DAS hulu dan tengah, diperlukan pihak ketiga baik dari pihak pemerintah maupun pihak lain, sehingga kerjasama yang disepakati dapat saling menguntungkan kedua belah pihak, mampu beroperasi dan berjalan berkelanjutan (Komarawidjaja, 2017). Pengelolaaan DAS berbasis masyarakat dilaksanakan secara terencana dan terpadu dengan melibatkan peran serta berbagai unsur masyarakat bersamasama Pemerintah Kabupaten/Kota serta unsur swasta yang didukung oleh Forum 
Koordinasi Pengelolaan DAS

Kabupaten/Kota melalui kerjasama lintas daerah dengan mengembangkan sistem kompensasi/IJL (Sudarwanto, 2018).

Wadah kerjasama kompensasi/IJL dalam kegiatan KTA melalui pengelolaan DAS dikoordinasi oleh Forum Koordinasi Pengelolaan DAS. Forum ini memiliki tujuan untuk memberikan arahan yang efektif sebagai bagian dari pengembangan kelembagaan dalam pengelolaan DAS dari hulu ke hilir secara utuh sebagaimana diatur dalam Peraturan Menteri Kehutanan Republik Indonesia Nomor P.61/Menhut-II/2013 Tentang Forum Koordinasi Pengelolaan Daerah Aliran Sungai. Pasal 10 Peraturan Menteri Kehutanan Republik Indonesia Nomor P.61/Menhut-II/2013 menyebutkan bahwa salah satu fungsi Forum Koordinasi Pengelolaan DAS adalah melaksanakan koordinasi dan konsultasi untuk menyelaraskan kepentingan antar sektor, antar wilayah dan antar pemangku kepentingan dalam Pengelolaan DAS
Terpadu baik Tingkat Provinsi maupun Tingkat Kabupaten/Kota. Selain diatur dalam Peraturan Menteri Kehutanan Republik Indonesia Nomor P.61/MenhutII/2013 Tentang Forum Koordinasi Pengelolaan Daerah Aliran Sungai, fungsi forum sebagai koordinator ditegaskan pula dalam Surat Edaran Kementerian Dalam Negeri tentang Pedoman Umum Pengelolaan Daerah Aliran Sungai Berbasis Masyarakat Nomor 413.2/8162/PMD.

IJL kegiatan KTA dari masyarakat hilir sebagai penerima manfaat kepada masyarakat hulu sebagai penyedia jasa dilakukan melalui pengelolaan DAS Terpadu berbasis masyarakat dan berkelanjutan, sebagai koordinator yaitu Forum Koordinasi Pengelolaan DAS. Bersama pemerintah provinsi dan/atau pemerintah kabupaten/kota, Forum Koordinasi Pengelolaan DAS membentuk tim Ad Hoc yang memiliki tugas mengelola dana Jasa Lingkungan. Mekanisme sistem pembayaran jasa lingkungan dapat dilihat dalam skema berikut ini: 


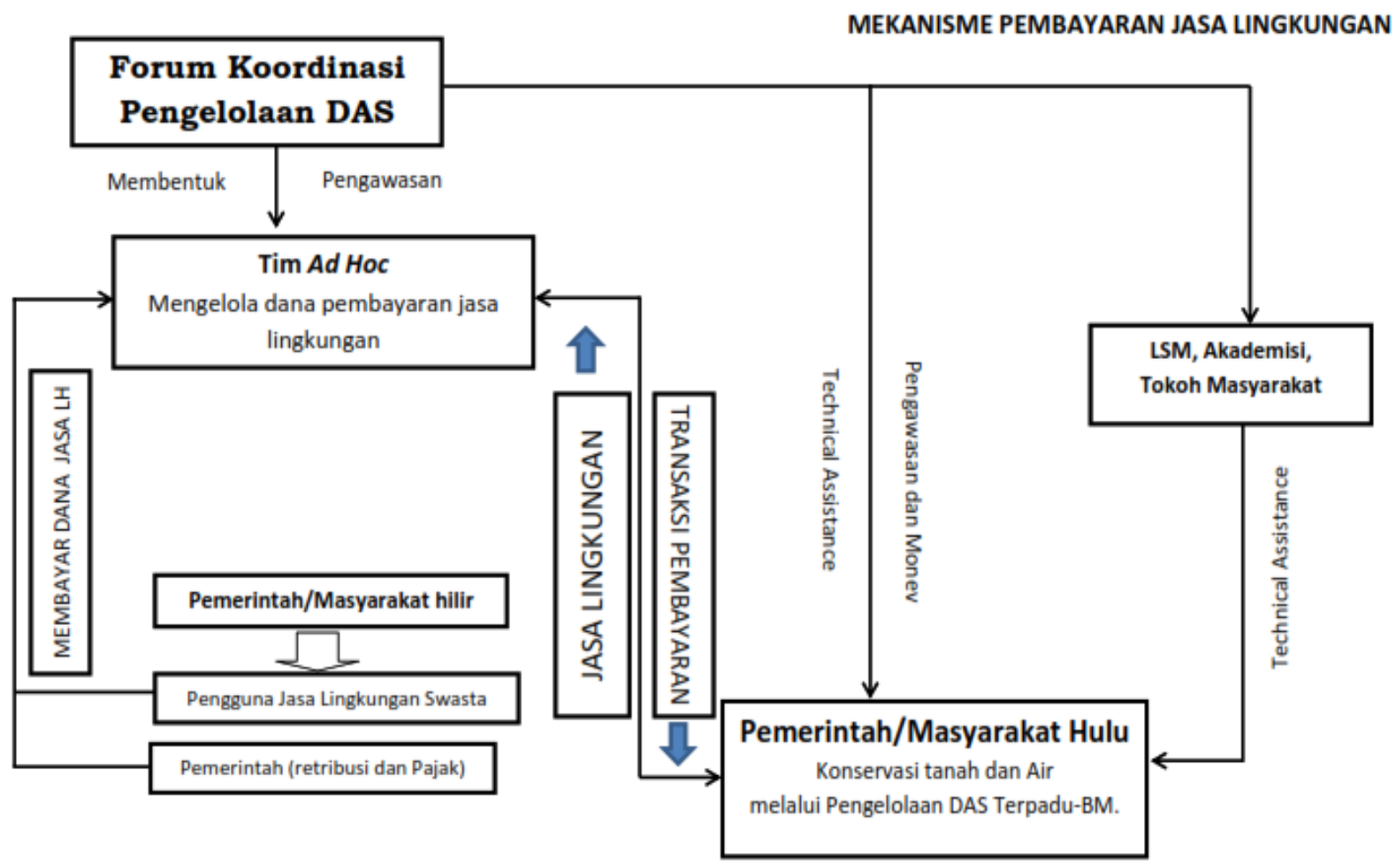

Gambar (Figure) 1. Mekanisme tarif jasa konservasi air dan lingkungan (Mechanism of the service fee of water and environment conservation)

Sumber (Source) : Analisis data (Data analysis), 2019

Konsep pembayaran dana IJL dilakukan oleh masyarakat hilir sebagai penerima manfaat kepada masyarakat hulu sebagai penyedia jasa. Sistem pembayaran jasa lingkungan dilakukan melalui lembaga pengelola jasa lingkungan ( $\mathrm{Tim} \mathrm{Ad} \mathrm{Hoc}$ ) yang dikoordinasikan oleh Forum koordinasi Pengelolaan DAS, kemudian diberikan kepada masyarakat hulu (penyedia jasa) untuk dimanfaatkan dalam kegiatan konservasi di wilayah hulu. Adapun realisasi pembayaran jasa lingkungan didasarkan pada peraturan perundang-undangan, dalam bentuk Peraturan Menteri Lingkungan Hidup dan Kehutanan tentang pengembangan sistem Pembayaran Jasa Lingkungan Hidup sebagai amanat Peraturan Pemerintah
Nomor 46 Tahun 2017 tentang Instrumen Ekonomi Lingkungan Hidup.

\section{KESIMPULAN}

Pijakan yuridis mengenai IJL kegiatan KTA sudah diatur dalam Undang-Undang Nomor 37 Tahun 2014 tentang Konservasi Tanah dan Air serta Peraturan Pemerintah Nomor 46 Tahun 2017 Tentang Instrumen Ekonomi Lingkungan Hidup, namun belum ada pengaturan mekanisme standar/teknis dalam pelaksanaan penghitungan dan pembayaran IJL. Oleh karena itu pembayaran jasa lingkungan dilakukan melalui lembaga pengelola jasa lingkungan (Tim $A d \quad H o c)$ yang dikoordinasikan oleh Forum Koordinasi Pengelolaan DAS bersama pemerintah provinsi dan/atau pemerintah kabupaten/ 
kota. Pembayaran IJL dari masyarakat hilir sebagai penerima manfaat kepada masyarakat hulu sebagai penyedia jasa perlu diatur dalam suatu Peraturan Daerah (Perda) tentang pengelolaan DAS, dimana salah satu klausul pasalnya menyebutkan kerjasama lintas daerah dalam pengelolaan DAS antar wilayah.

Sebagai saran, Pemerintah perlu segera mewujudkan Peraturan Pemerintah sebagai aturan pelaksanaan IJL dan pendanaan penyelenggaraan KTA dan perlu diatur lebih lanjut secara teknis dalam bentuk peraturan menteri. Kementerian Lingkungan Hidup dan Kehutanan perlu segera menindaklanjuti amanat Peraturan Pemerintah Nomor 46 Tahun 2017 Tentang Instrumen Ekonomi Lingkungan Hidup dengan Peraturan Menteri Lingkungan Hidup dan Kehutanan tentang Sistem Pembayaran Jasa Lingkungan Hidup sebagai pengaturan dalam pelaksanaan mekanisme IJL kegiatan KTA, dari penerima manfaat KTA, kepada masyarakat yang melakukan jasa KTA. Selain itu, Forum Koordinasi Pengelolaan DAS dengan tugas dan fungsi memberikan masukan dalam pengelolaan DAS bersama pemerintah perlu segera mewujudkan tim Ad Hoc pengelola dana jasa lingkungan dalam upaya pengelolaan dan pemanfaatan DAS berkelanjutan.

\section{UCAPAN TERIMAKASIH :}

Penulis sampaikan ucapan terimakasih kepada Pengurus Pusat Masyarakat Konservasi Tanah dan Air Indonesia (MKTI) serta Ketua Panitia Penyelenggara
Seminar Nasional ke IX dan Kongres Nasional X MKTI 2019.

\section{DAFTAR PUSTAKA}

Arafat, F., Wulandari, C., \& Qurniati, R. (2015). Kesediaan menerima pembayaran jasa lingkungan air sub das way betung hulu oleh masyarakat kawasan hutan register 19 (studi kasus di Desa Talang Mulya Kecamatan Padang Cermin Kabupaten Pesawaran). Jurnal Sylva Lestari, 3(1), 21-30.

Dasrizal, Ansofino, Juita, E., \& Jolianis. (2012). Model Sistem Pembayaran Jasa Lingkungan dalam Kaitannya dengan Konservasi Sumberdaya Air dan Lahan: Studi Kasus pada Batang Anai Sumatera Barat. Economica: Jurnal Program Studi Pendidikan Ekonomi STKIP PGRI Sumatera Barat, 1(1), 14-31.

Fatahilah, M. (2013). Kajian Keterpaduan Pengelolaan Daerah Aliran Sungai (DAS) Garang Provinsi Jawa Tengah. Jurnal Geografi: Media Informasi Pengembangan dan Profesi Kegeografian, 10(2), 136153.

Heryani, N., \& Sutrisno, N. (2013). Teknologi Konservasi Tanah dan Air untuk Mencegah Degradasi Lahan Pertanian Berlereng. Jurnal Penelitian dan Pengembangan Pertanian, 32(3), 122-130.

Idrus, S., Ismail, A., \& Ekayani, M. (2016). Potensi Pembayaran Jasa Lingkungan Hutan Mangrove di Kecamatan Jailolo Kabupaten Halmahera Barat. Jurnal IImu Pertanian Indonesia, 21(3), 195202. 
Katharina, R. (2007). Adopsi Konservasi Sebagai Bentuk Investasi Usaha Jangka Panjang (Studi Kasus Usahatani Kentang Lahan Kering Dataran Tinggi Pangalengan). Jurnal Manajemen \& Agribisnis, 4(1), 32-45.

Komarawidjaja, W. (2017). Prospek Pemanfaatan Penyaring Sampah Sungai dalam Implementasi Imbal Jasa Lingkungan di Daerah Aliran Sungai Ciliwung Segmen 2 Kota Bogor. Jurnal Teknologi Lingkungan, 18(1), 37-44.

Napitupulu, D. F., Asdak, C., \& Budiono, B. (2013). Mekanisme Imbal Jasa Lingkungan di Sub-DAS Cikapundung (Studi Kasus pada Desa Cikole dan Desa Suntenjaya Kabupaten Bandung Barat). Jurnal IImu Lingkungan, 11(2), 73-83.

Peraturan Menteri Kehutanan Republik Indonesia Nomor P.61 Tahun 2013. Forum Koordinasi Pengelolaan DAS. 1 November 2013. Berita Negara Republik Indonesia Tahun 2013 Nomor 1345. Jakarta.

Peraturan Pemerintah Nomor 46 Tahun 2017. Instrumen Ekonomi Lingkungan Hidup. 10 November 2017. Lembaran Negara Republik Indonesia Tahun 2017 Nomor 228. Jakarta.

Riska, Y., Bambang, A. N., \& Budiyono. (2013). Identifikasi Pemanfaatan Jasa Lingkungan Air di KSA/KPA Merapi Propinsi Sumatera Barat. Prosiding Seminar Nasional Pengelolaan Sumberdaya Alam dan Lingkungan, Semarang.
Samedi, S. (2015). Konservasi Keanekaragaman Hayati di Indonesia: Rekomendasi Perbaikan Undang-Undang Konservasi. Jurnal Hukum Lingkungan Indonesia, 2(2), 1-28.

Sudarma, I. M. (2014). Pembayaran Jasa Lingkungan Sebagai Instrumen Ekonomi Menuju Pembangunan Berkelanjutan. Prosiding Seminar Nasional Integrasi Keanekaragaman Hayati Dan Kebudayaan Dalam Pembangunan Berkelanjutan, Denpasar, Bali.

Sudarwanto, A. S. (2018). Pijakan Yuridis dan Rekonstruksi Kelembagaan Pengelolaan Daerah Aliran Sungai Berbasis Masyarakat. Prosiding Seminar Nasional "Pengelolaan Daerah Aliran Sungai (DAS) Terpadu Menuju Kelestarian Fungsi Lingkungan dan Kesejahteraan Masyarakat", Surakarta.

Sudiyono, S. (2012). Pengelolaan Sumberdaya Air di Kabupaten Lombok Barat: Sebuah Potret Implementasi Kebijakan Ekonomi Hijau (Water Resources Management In West Lombok District: A Portrait of Green Economy Policy Implementation). Jurnal Masyarakat dan Budaya, 14(3), 571-598.

Sutopo, M. F., Sanim, B., Saukat, Y., \& Mawardi, M. I. (2011). Analisis kesediaan membayar jasa lingkungan dalam pengelolaan sumberdaya air minum terpadu di indonesia (studi kasus DAS cisadane hulu). Jurnal Teknologi Lingkungan, 12(1), 17-23. 
Undang-Undang Nomor 32 Tahun 2009. Perlindungan dan Pengelolaan Lingkungan Hidup. 3 Oktober 2009. Lembaran Negara Republik Indonesia Tahun 2009 Nomor 140. Jakarta.

Undang-Undang Nomor 37 Tahun 2014. Konservasi Tanah dan Air. 17 Oktober 2014. Lembaran Negara Republik Indonesia Tahun 2014 Nomor 299. Jakarta.
Wahyudi, W. (2014). Teknik Konservasi Tanah serta Implementasinya pada Lahan Terdegradasi dalam Kawasan Hutan. Jurnal Sains \& Teknologi Lingkungan, 6(2), 71-85.

Wardah, W., \& Farsia, L. (2013). Penerapan Imbal Jasa Lingkungan dalam Pelestarian Daerah Aliran Sungai di Aceh. Kanun: Jurnal IImu Hukum, 15(1), 115-129. 